\title{
Penafsiran Amilenialisme \& Teologi Kovenan Dalam Memahami Alkitab
}

\author{
Philip Suciadi Chia ${ }^{1)}$ Juanda $^{2)}$ \\ 1) Southern Baptist Theological Seminary - Kentucky USA \\ E-mail: pchia275@students.sbts.edu \\ 2) Evangelical Theological Seminary of Indonesia - Surabaya \\ E-mail: juanda@sttii-surabaya.ac.id
}

\begin{abstract}
There are various choices in understanding the Bible to become dogma in a church. Whether it was built based on a guide from the Bible and the traditions of the apostles or church fathers, to those who only focus on the Bible. Those based only on the Bible also have their own uniqueness. Amillennialism believes that the church is in the entire Old Testament. Paul, for example, uses the church that leads to Israel (Gal. 6:16). In addition, the remnants of the Israelites in the OT were said to be the church (Acts 7:38). The church is already in the OT with the election of the nation of Israel to be God's people. Even further, followers of amillennialism believe that the church existed in the garden of Eden. Covenant theology bases its theological understanding and the study of the Bible is based on three covenants namely the work agreement, redemption and grace. Covenant theology can be said to be a new theology, not even in the days of the church fathers. Even so, Augustine did mention the relationship of Adam, who at first, stood before God as a covenant. The exposition of the book of Revelation, according to the Covenant Theologian, is based on the method of progressive parallelism which is divided into seven parts. The seven parts are parallel with each other. Each section also reveals a certain progression in the process of eschatology. Although the book of Revelation is divided into seven parts, it should not only pay attention or focus on one part, but should appreciate all parts of the book of Revelation as a whole.
\end{abstract}

Keywords: Amillennialism, Covenant theology,Revelation, Bible.

\begin{abstract}
Abstrak
Ada aneka pilihan di dalam memahami Alkitab untuk bisa menjadi dogma dalam sebuah gereja. Entah yang dibangun berdasar perpanduan dari Alkitab dan tradisi para rasul atau bapa gereja, hingga yang hanya fokus kepada Alkitab semata. Yang mendasarkan pada Alkitab saja, juga memiliki keunikannya masing-masing. Kaum amilenialisme meyakini bahwa gereja sudah ada di dalam seluruh Perjanjian Lama. Paulus, contohnya, memakai gereja yang mengarah kepada Israel (Gal. 6:16). Di samping itu, sisa-sisa orang Israel di dalam PL dikatakan sebagai gereja (Kis. 7:38). Gereja sudah ada di dalam PL dengan pemilihan bangsa Israel menjadi umat Allah. Bahkan lebih jauh lagi, penganut amilenialisme percaya bahwa gereja sudah ada ketika di taman Eden.Teologi kovenan mendasarkan pemahaman teologis maupun penelahaan Alkitabnya berdasarkan dari tiga perjanjian yaitu perjanjian kerja, penebusan dan anugerah. Teologi perjanjian dapat dikatakan suatu teologi yang baru, bahkan belum ada pada masa bapa-bapa gereja.
\end{abstract}


Meskipun demikian, Agustinus memang pernah menyinggung hubungan Adam, yang pada mulanya, berdiri di hadapan Allah sebagai perjanjian. Eksposisi kitab Wahyu, menurut Teolog Kovenan, didasarkan pada metode paralelisme progresif yang terbagi menjadi tujuh bagian. Ketujuh bagian tersebut bersifat paralel satu dengan lainnya. Masing-masing bagian juga menyingkapkan akan progresivitas tertentu dalam proses eskatologi. Meskipun kitab Wahyu terbagi atas tujuh bagian, namun tidak boleh hanya memperhatikan atau terfokus pada satu bagian saja, tetapi hendaknya menghargai semua bagian dalam kitab Wahyu sebagai keseluruhan.

Kata Kunci: amilenialisme, Teologi kovenan, Wahyu, Alkitab.

\section{LATAR BELAKANG}

Bentuk pandangan eskatologi amilenalisme selalu dianut oleh tokohtokoh teologi perjanjian. Akan tetapi, tokoh teologi perjanjian, belum tentu menganut akan amilenialisme sebagai pandangan eskatologisnya.

Ada beberapa tokoh teologi perjanjian yang tidak menganut amilenialisme seperti, George Eldon Ladd (premilenialisme) maupun L. Boettner (postmilenialisme). Dengan demikian, penulis akan membahas mengenai teologi perjanjian yang berpegang teguh pada paham amilenialisme.

Oleh karena itu, perihal-perihal yang akan dibahas meliputi definisi, dasar doktrinal dari teologi perjanjian, latar belakang sejarah, sistem hermeneutika yang dipakai, eskatologi yang dikemukakan oleh amilenialisme maupun eksposisi yang dipakai oleh teolog kovenan yang beraliran amilenialisme dalam menelaah kitab Wahyu.

\section{ETIMOLOGI}

Kata perjanjian berasal dari kata Ibrani yakni 'Berith' atau dalam bahasa Yunani sering disebut juga 'diatheke'. Istilah 'Berith' memiliki arti covenant, league, confederacy. Di samping itu, kata 'Berith' digunakan sebanyak 280 kali di dalam seluruh Perjanjian Lama. ${ }^{1}$ Ada dua pandangan yang berpendapat mengenai asal kata 'Berith' ini, yakni (1) Pandangan umum yang menganggap bahwa kata ini diturunkan dari kata Ibrani 'barah' yang berarti memotong. ${ }^{2}$

(2) VINE'S mengatakan bahwa kata ini berasal dari bangsa Akadia, yang berarti memakai. ${ }^{3}$ Di samping itu, Berkhof menambahkan: "Kata 'Berith' [ mungkin menunjukkan suatu persetujuan antara satu pihak dengan pihak lain (dipleuric), tetapi juga disposisi atau maksud kehendak yang dinyatakan satu pihak kepada pihak lain (monopleuric). Namun, arti kata yang tepat tidaklah tergantung pada etimologi kata tersebut dan juga pada perkembangan historis konsep tersebut, tetapi lebih terkait pada kedua belah pihak yang terkait.

\footnotetext{
${ }^{2}$ Eddy Peter, Teologi Perjanjian Versus Dispensasionalisme (Tangerang: STT Philadephia, 2004), 6. ${ }^{3}$ Geoffrey W. Bromiley, Historical Theology: An Introduction (Grand Rapids: Eerdmans, 1978), 1-2.

${ }^{1}$ Johanes Behm, "Berith", Theological Dictionary of The New Testament, Vol. III, ed. Herhard Kittel (Grand Rapids: Wm. B. Eerdmans Publishing Company, 1965), 50.
} 
Jurnal Teologi \& Pelayanan ( Kerusso )

E-ISSN: 2714-9587

P-ISSN: 2407-554X

Perjanjian ini menuntut sifat disposisi dari satu pihak kepada pihak lain". ${ }^{4}$

Sedangkan kata 'diatheke' dalam LXX diterjemahkan dari kata Ibrani, yakni 'berith'. Kata ini dipakai dalam beberapa arti seperti: perjanjian dua sahabat (1 Sam. 18:3), perjanjian yang memiliki kekuatan hukum (1 Sam. 20:8), perjanjian antara dua penguasa untuk saling tidak menyakiti rakyatnya (Kej. 21:23; 26:26; 1 Taw. 5:12), perjanjian antara dua raja mengenai kerajaan mereka maupun dua suku (Yos. 15:9), perjanjian Israel dengan hambahamba Israel (Yer. 34:8) dan dalam nuansa bahasa Ibrani dipakai perjanjian antara Raja dengan hamba-hambanya. ${ }^{5}$ Inilah pelbagai pemakaian kata 'berith' di dalam PL.

Apabila digunakan dalam PB (diatheke), hal ini berhubungan dengan perjamuan Tuhan (1 Kor. 11:25; Mark. 14:24; Mat. 26:28; Luk. 22:20). Dengan demikian, berith (Ibrani) atau diatheke (Yunani) ini sering digunakan di dalam Alkitab.

Setiap pengaturan lebih atau kurang resmi antara dua atau lebih pihak dapat disebut sebagai perjanjian. Kadang-kadang perjanjian hanya merupakan janji dan tidak melibatkan, entah itu kondisi atau izin dari pihak salah satu pihak. Namun, lebih sering istilah perjanjian ini melibatkan kesepakatan perjanjian antara dua pihak atau lebih dan bersifat kondisional. ${ }^{6}$ Dengan demikian, berdasarkan arti kamus dan etimologi kata perjanjian mengarah kepada suatu kesepakatan baik antara dua pihak atau lebih dan sering kali bersifat kondisional atau bersyarat.

\footnotetext{
${ }^{4}$ Louis Berkhof, Teologi Sistematika, Vol II (Jakarta: Lembaga Reformed Injili Indonesia, 1995), 179.

${ }^{5}$ Colin Brown, Dictionary of New Testament Theology (Grand Rapids: Michigan, Zondervan Publishing House), 366.

${ }^{6}$ J. Oliver Buswell, A Systematic Theology of

Christian Religion Vol. II (Grand Rapids:

Zondervan, 1962), 307.
}

\section{MENURUT TOKOH TEOLOGI PERJANJIAN}

Teologi perjanjian dapat didefinisikan sebagai sistem teologi yang didasarkan pada konsep sebelum kejatuhan yaitu ketika manusia berada di bawah perjanjian kerja dengan Allah. Perjanjian ini merupakan janji Allah kepada Adam untuk memberikan kebahagiaan kekal apabila ia dapat memelihara hukum Allah dengan sempurna. Namun tidak hanya itu, ketika kejatuhan manusia pun, Allah tetap memberikan janji kepada manusia dengan rahmat dan kasih karunianya secara khusus bagi mereka yang beriman kepada Kristus. ${ }^{7}$

Collins menambahkan bahwa teologi perjanjian dapat dibedakan dan diketahui dari 'tempat di mana perjanjian itu diberikan', karena hal ini menyajikan seluruh isi Kitab Suci yang diliputi oleh perjanjian-perjanjian, yaitu perjanjian kerja dan perjanjian anugerah. ${ }^{8}$

Berdasarkan definisi inilah, teologi perjanjian mendasarkan akan pemahaman teologisnya. Dengan kata lain, teologi perjanjian merupakan suatu sistem teologi yang berdasarkan pada dua perjanjian (kerja dan anugerah) yang dapat menolong untuk mengerti akan Alkitab secara keseluruhan. Namun ada beberapa teolog perjanjian yang menambahkan perjanjian penebusan pula sebagai dasar teologi.

\section{DASAR TEOLOGI PERJANJIAN}

Ada tiga dasar doktrinal dari Teologi Perjanjian yang mendasari pemahamannya

\footnotetext{
${ }^{7}$ M. E Osterhaven, “Covenant Theology”, ed.Walter A. Well dalam Evangelical Dictionary of Theology (Grand Rapids: Baker House, 1984), 280.

${ }^{8}$ George N. M Collins, "Covenant Theology," Baker's Dictionary of Theology (Grand Rapids: Baker Book House, 1960), 144.
} 
akan Kitab Suci, yakni perjanjian kerja, penebusan dan anugerah.

Doktrin yang pertama ialah perjanjian kerja. Doktrin ini mencerminkan upah dari ketaatan. Oleh karena itu, disebut sebagai perjanjian kerja karena perbuatan merupakan syarat yang dihubungkan dari janji itu. Di dalam teologi perjanjian, perjanjian kerja dapat dikatakan sebagai persetujuan antara Allah dengan adam, menjanjikan kehidupan kekal apabila ia taat dan juga hukuman yang berupa kematian bagi yang gagal.

Akan tetapi, Adam berdosa dan manusia gagal untuk memenuhi persyaratan dari perjanjian kerja yang telah diberikan Allah. Oleh karena itu, perjanjian yang kedua yaitu perjanjian anugerah diberikan oleh Allah. Berkhof mengatakan bahwa hal ini sebagai kesepakatan akan anugerah yang luar biasa antara Allah dengan manusia yang berdosa. Allah kemudian menjanjikan keselamatan kekal bagi umat manusia melalui iman kepada Yesus Kristus dan ketaatan. ${ }^{9}$

Perjanjian Kerja ini, secara implisit, pada mulanya terdapat di dalam Kejadian 2:16-17 ketika Allah menetapkan persyaratan-persyaratan untuk perjanjian yang melibatkan kesepakatan antara Allah dengan manusia. Persyaratan yang Allah berikan kepada Adam merupakan ketaatan kepada Allah secara sempurna, yaitu dengan cara tidak memakan buah dari pengetahuan yang baik dan jahat (Kej. 2:17). Prinsip kovenan ini juga disebutkan dalam Imamat 18:5; Yehezkiel 20:11, 13, 20; Lukas 10:28; Roma 7:10; 10:15; dan Galatia 3:12. Ayat-ayat ini berbicara mengenai hukum yang bertujuan memberikan hidup. ${ }^{10}$

Doktrin yang kedua ialah perjanjian penebusan. Perjanjian ini dibuat antara Allah Bapa dengan Allah Putra sejak

\footnotetext{
${ }^{9}$ Louis Berkhof, Systematic Theology (Grand Rapids: Wm. B. Eerdmans Publishing Co., 1941), 277.

${ }^{10}$ Carl F. Henry, Basic Christian Doctrines (New York: Holt, 1962), 117-119.
}

kekekalan ketika mereka "membuat perjanjian bersama untuk menebus umat manusia. Bapa memilih Putra untuk menjadi mediator; Adam yang kedua, untuk menyelamatkan dunia, dan Putra Allah menerima perintah ini dengan melakukan pekerjaan yang Bapa berikan kepada-Nya dan akan memenuhi semua kebenaran dengan menaati hukum Allah.

Ada banyak ayat Alkitab yang menekankan natur kekekalan dari rencana keselamatan (Ef. 1:3-14; 3:11; 2 Tes. 2:13; 2 Tim. 1:9; Yak. 2;5; 1 Ptr. 1:1:2). Lebih lanjut, Kristus menunjuk kepada kedatangan-Nya sebagai utusan (Yoh. 5:30, $43 ; 6: 38-40 ; \quad 17: 4-12)$. Kristus juga dinyatakan sebagai wakil dari umat manusia, kepala daripada perjanjian $(\mathrm{Rm}$. 5:12-21; 1Kor. 15:22). ${ }^{11}$ Dalam rencana kekal Allah, ditetapkan bahwa Bapa akan merencanakan penebusan melalui pilihan dan predestinasi; Putra Allah akan menyediakan penebusan melalui kematianNya untuk menebus dosa; Roh Kudus akan mengefektifkan rencana itu melalui melahirkan baru dan memeteraikan orang percaya.

Akan tetapi, perjanjian ini telah dibuat di dalam kekekalan masa lampau dan menjadi dasar bagi perjanjian anugerah, hanya bagi Allah dengan orang-orang pilihan-Nya saja.

Dengan kata lain, perjanjian penebusan ini dapat berarti "kesepakatan antara Bapa yang memberikan Anak sebagai Kepala dan Penebus dari umat pilihan, dan Anak yang secara sukarela mengambil tempat dari mereka yang Bapa telah berikan kepada-Nya". ${ }^{12}$

Doktrin yang ketiga ialah perjanjian anugerah. Perjanjian ini dibuat oleh Allah dengan orang pilihan yang Ia tawarkan keselamatan bagi orang yang berdosa di dalam Kristus. Allah telah memberikan

\footnotetext{
${ }^{11}$ Berkof, Systematic Theology, Vol. IV. 211-218.

${ }^{12}$ Louis Berkof, Summary of Christian Doctrine (Grand Rapids: Eerdmans, 1938), 80-89.
} 
Putra-Nya sebagai jaminan untuk keselamatan kita. Melalui anugerah-Nya, Allah memampukan manusia untuk memenuhi tuntutan dari tanggung-jawab dengan memberikan Roh Kudus. Perjanjian ini bersifat kekal dan tidak dapat berubah. Allah akan selamanya setia pada perjanjian yang Ia telah janjikan dan sediakan. Dengan demikian, perjanjian anugerah merupakan tindakan Allah yang telah memberikan anugerah dengan cuma-cuma dan memberikan berkat kepada semua orang yang percaya kepada Kristus. ${ }^{13}$

Dengan demikian, teologi kovenan mendasarkan pemahaman teologis maupun penelahaan Alkitabnya berdasarkan dari tiga perjanjian yaitu perjanjian kerja, penebusan dan anugerah.

\section{TEOLOGI PERJANJIAN}

Teologi perjanjian dapat dikatakan suatu teologi yang baru, bahkan belum ada pada masa bapa-bapa gereja. Meskipun demikian, Agustinus memang pernah menyinggung hubungan Adam, yang pada mulanya, berdiri di hadapan Allah sebagai perjanjian. Hal ini dituliskan di dalam bukunya yang berjudul De Civitates Dei. Di samping itu, ada beberapa bapa gereja yang memandang perjanjian ini terdapat di dalam Hosea 6:7. ${ }^{14}$

Akan tetapi, doktrin akan teologi perjanjian belumlah nyata hadir dan berkembang. Hal ini mendapat dukungan dari Berkhof yang mengatakan, "Pada masa bapa-bapa gereja, ide tentang perjanjian ini tidak benar-benar telah ditemukan". ${ }^{15}$ Teologi ini bahkan tidak muncul pada masa abad pertengahan bahkan masa reformis, Luther, Calvin, Swingli ataupun

\footnotetext{
${ }^{13}$ Www.lifefebc.com/kovenan

${ }^{14}$ Nats ini berbunyi, "Tetapi mereka itu telah melangkahi perjanjian di Adam, di sana mereka telah berkhianat terhadap aku".

${ }^{15}$ Www.wikipedia.com/covenanttheology

${ }^{16}$ Cornelius Van Til, "The idea of covenant theology has only in modern times been broadly
}

Melancthon. Meskipun teologi perjanjian tergolong muda, tidak berarti tidak Alkitabiah, bahkan teologi ini kemudian menyebar cepat di kalangan reformator dan diakui pada akhir abad 16. ${ }^{16}$ Bear, seorang teolog perjanjian, menambahkan:

Tentu saja, doktrin-doktrin dapat saja baru akan tetapi belum tentu salah. Kami percaya bahwa Roh Kudus dapat memimpin Gereja ke dalam pengertian yang baru akan kebenaran. Lagipula, suatu doktrin dapat saja baru di dalam perkembangan lanjutan dari doktrin sebelumnya, atau dapat saja menimbulkan pertentangan dengan pandangan sebelumnya. Kendati demikian, pandangan yang baru muncul bisa saja benar karena berdasarkan dari pengamatanpengamatan yang lebih cermat. ${ }^{17}$

Orang-orang yang mendukung teologi ini (untuk pertama kalinya) merupakan reformator-reformator yang menentang akan aliran keras dari predestinasi yang dikemukakan oleh reformator dari Prancis dan Swiss.

Johann Bullinger (1504-1575) mengikuti Ulrich Zwingli sebagai pemimpin Reformasi di Zurich. Sebagaimana halnya dengan para reformator yang lain, ia juga berpegang pada otoritas dari Kitab Suci. Di samping itu, ia juga banyak menulis buku (sebanyak 150 buku) dan merupakan pemimpin yang berpengaruh dalam gereja Reformed. Ia sangat berperan dalam perkembangan teologi perjanjian. ${ }^{18}$

Johannes Wollebius (1586-1629) merupakan dosen Perjanjian Baru (PB) di Basel. Ia mengajarkan bahwa Allah membuat suatu perjanjian kerja dengan Adam di mana Allah berkuasa atas manusia sebelum kejatuhan. Wollebius menjelaskan

\footnotetext{
conceived", Twentieth Century Encyclopedia (Grand Rapids: Baker Book House, 1955), 306.

${ }^{17}$ James E. Bear, Dispensationalism and the Covenant of Grace (Richmond: Union Seminary Review, 1938), 4.

${ }^{18}$ Heinrich Heppe, Reformed Dogmatics (Grand Rapids: Baker,1978), 283.
} 
perjanjian kerja yaitu 'janji kehidupan kekal bagi mereka yang taat dan ancaman kematian bagi mereka yang tidak taat'.

Ia memahami pohon pengetahuan yang baik dan jahat sebagai sakramen dari perjanjian kerja. Ia pun juga mengajarkan akan perjanjian anugerah yang dibuat berdasarkan kemurahan Allah setelah kejatuhan. Perjanjian anugerah yang disebarkan sepanjang abad setelah kejatuhan yang diperantarai oleh Kristus. Ia merujuk pada PL dan PB.

PL meliputi tiga zaman yakni dari Adam sampai Abraham, Abraham sampai Musa dan Musa sampai Kristus. PB merupakan masa setelah kedatangan Kristus. Di samping itu, ia menekankan pula akan lima perbedaan di antara dua pelaksanaan perjanjian yaitu yang terdapat pada PL dan PB. Sakramen-sakramen perjanjian kerja adalah sunat dan upacara paskah di PL. PB sakramen kerjanya ialah baptisan dan perjamuan Tuhan. ${ }^{19}$

$$
\text { William Ames }
$$

merupakan seorang teolog Puritan yang dihormati di Inggris dan Belanda. Ia secara gigih menentang Arminianisme. Ia pun juga mengajarkan perjanjian kerja yang didirikan sebelum kejatuhan.

Akan tetapi, Ames berpandangan bahwa perjanjian kerja lingkupnya universal dan diteruskan setelah kejatuhan. Namun dalam penggenapannya bergantung kepada ketaatan manusia kepada Allah. Di lain pihak, ia pun mengajarkan akan perjanjian anugerah yang dibuat setelah kejatuhan, tetapi ia lebih memilih untuk menyebutnya sebagai perjanjian karena hal itu berkaitan dengan kematian Kristus.

Ames melihat Allah sebagai partisipan tunggal dalam perjanjian anugerah. Ia mengajarkan tentang kecukupan universal tetapi penerapannya hanya terbatas pada mereka yang dimaksudkan oleh Allah. Ames juga

${ }^{19}$ Paul Enns, The Moody Handbook of Theology (Malang: Seminari Alkitab Asia Tenggara, 2004), 140. memahami bahwa perjanjian anugerah dilaksanakan di PL dan PB; di PL meliputi dua zaman yakni sebelum Musa dan sesudah Musa. PB meliputi dua zaman juga yakni dari Kristus hingga akhir zaman dan akhir dari semuanya itu. Pada akhirnya tujuan perjanjian akan tercapai: kemuliaan Allah dan keselamatan manusia. Tanda dari perjanjian anugerah adalah baptisan. Oleh karena itu, bayi harus dibaptiskan. ${ }^{20}$

Johannes Cocceius (1603-1669) ia merupakan pemimpin dalam perkembangan teologi perjanjian. Teologi perjanjian menjadi semakin jelas dalam tulisannya. Ia menekankan akan suatu eksegetikal teologi yang alkitabiah di mana ia mengakui kebutuhan akan suatu teologi yang berasal dari Kitab Suci itu sendiri sebagaimana yang telah dikemukakan oleh para reformator.

Ia mengajarkan bahwa Allah memasuki perjanjian kerja dengan Adam. Perjanjian ini memampukan Adam untuk menikmati persekutuan dan keintiman dengan Allah. Cocceius mengajarkan bahwa Adam mewakili seluruh umat manusia dalam perjanjian kerja itu.

Apabila Adam taat kepada Allah, maka ia akan sampai pada pengetahuan dan pemahaman bagi kebaikan dirinya; apabila ia tidak taat, ia akan masuk pada yang jahat atau kematian. Menurutnya, pohon kehidupan merupakan sakramen dari kota surgawi dan hidup kekal. ${ }^{21}$

Oleh karena Kristus hidup, maka pohon kehidupan menunjuk dari Putra Allah. Melalui dosanya, Adam menjadi bersalah, jatuh dari persekutuan dengan Allah, dari pengharapan akan hidup kekal, anugerah spiritual, kebenaran, otoritas atas makhluk ciptaan dan dari hidup secara fisik.

Kematian Kristus merupakan "jaminan yang telah efektif sejak awal bahkan sebelum Sang Putra, dalam pandangan jasa-Nya pada masa yang akan

\footnotetext{
${ }^{20} \mathrm{Www}$.4himnet.com/history

${ }^{21}$ Www.geocities.com/theology
} 
Jurnal Teologi \& Pelayanan ( Kerusso )

E-ISSN: 2714-9587

P-ISSN: 2407-554X

datang, telah memenuhi janji-Nya dengan menggenapi karya penebusan. ${ }^{22}$

\section{AMILENIALISME}

Beberapa teolog perjanjian telah mendapatkan unsur-unsur amilenial pada awal sejarah gereja. Diedrich H. Krommiga, seorang penganut premilenialisme dengan jelas melihat dalam surat Barnabas sebagai sebuah 'jenis eskatologi amilenial yang sangat awal'. ${ }^{23}$ Tidak hanya itu, Cox bahkan mengatakan bahwa ajaran amilenialisme setua ajaran Kristen itu sendiri. ${ }^{24}$

Berikut ini merupakan beberapa tokoh dari Bapa gereja yang diyakini menganut amilenialisme:

(1) Origenes (185-254 M). Beliau dapat dikatakan sebagai pencetus awal daripada paham amilenialisme. Ia yang memopulerkan akan metode alegoris ketika menafsirkan Alkitab. Di samping itu, ia pun meletakkan dasar hermeneutikanya pada Kerajaan Kristus yang telah dijanjikan, namun yang bersifat spiritual bukan di dunia. $^{25}$

(2) Eusebius (270-340 M). Beliau merupakan sahabat daripada Kaisar Romawi pada saat itu, Konstantine, melihat bahwa pemerintahan Romawi saat itu sebagai bukti dari Kerajaan Seribu Tahun. Ia pun menolak akan pandangan premilenialisme. ${ }^{26}$

(3) Tyconius, seorang donatur dari Afrika pada abad keempat, secara gamblang menolak akan eskatologi dan pandangan futuris pada Wahyu 20 yang harus digenapi secara harafiah. Ia mengemukakan bahwa

\footnotetext{
${ }^{22}$ William G.T Shedd, Dogmatic Theology

(Nashville: Nelson, 1980), 360.

${ }^{23}$ Millard J. Erickson, Pandangan Kontemporer

dalam Eskatologi (Malang: Seminari Alkitab Asia

Tenggara, 2004), 90.

${ }^{24}$ William E.Cox, Amillennialism Today (New

Jersey, Presbyterian and Reformed Publishing Co., 1977), 7

${ }^{25} \mathrm{Www}$.Theologicalstudies.com/westminster/father church.
}

saat ini merupakan masa Seribu Tahun dalam Alkitab dan mengemukakan bahwa 1000 tahun tidak boleh dimengerti secara harafiah. Ia pun juga memandang kebangkitan pertama dalam Wahyu 20:4 sebagai kebangkitan rohani. ${ }^{27}$

(4) Augustinus merupakan orang yang menganut akan pandangan amilenialisme. Ia kemudian memopulerkan pandangan ini secara luas dan akhirnya diterima pada konsili di Efesus pada tahun 431 Masehi. Ia mengemukakan pula bahwa premilenialisme merupakan pandangan yang percaya pada tahayul belaka. Ia mengajarkan bahwa pemerintahan milenial yang tertulis di Alkitab (Yes. 11; Yes. 65; Zak. 14 dan Why. 20) sudah terwujud dalam gereja. Ia percaya bahwa ketika gereja telah memenuhi janji secara kerajaan, maka tidak ada penggenapan secara literal untuk Israel. ${ }^{28}$

Dengan demikian, menurut buktibukti pada zaman bapa-bapa gereja dapat disimpulkan bahwa amilenialisme sebenarnya sudah ada sejak lama. Berkof mengemukakan bahwa beberapa dari kaum premilenialisme telah menganggap bahwa amilenialisme merupakan suatu pandangan yang baru.

Sesungguhnya hanya namanya saja yang baru, namun pandangannya ini setua ajaran Kristiani. Salah satunya ialah ajaran chiliasme yang beredar di kalangan bapabapa gereja pada abad kedua hingga ketiga.

Pada masa itu, ajaran ini sungguh diterima secara luas bahkan menjadi suatu pengakuan di dalam gereja purba dan sekarang dipegang oleh teologi Reformed. ${ }^{29}$ Oleh sebab itu, tokoh-tokoh amilenialisme

\footnotetext{
${ }^{26}$ Ibid.

${ }^{27}$ Www.Theologicalstudies.com/westminster/father church2.

${ }^{28}$ Www.reformedreader.org/fatherschurch

${ }^{29}$ Berkof, The Second Coming of Christ (Grand Rapids: Wm. B. Eerdmans Publishing Company, 1953), 34.
} 
menolak apabila pandangan eskatologinya dikatakan sebagai suatu ajaran baru karena nyatanya sudah ada pada zaman bapa-bapa dan diturunkan hingga masa kini.

Mereka membela bahwa mayoritas dari bapa-bapa gereja, tokoh reformator dan orang-orang yang memiliki reputasi baik dalam penafsiran Alkitab, memegang amilenialisme. Walvoord mengakui bahwa eskatologi reformed maupun tokoh-tokoh reformasi mayoritas menganut amilenialisme yang cenderung mengikuti ajaran Augustinus. ${ }^{30}$ Menurut Walvoord, Augustinus (400 M) inilah yang kemudian dikenal sebagai orang yang mensistematiskan dan mengembangkan ajaran amilenialisme.

Augustinus menyatakan bahwa milenium tidak secara khusus bersifat sementara atau kronologis. Meskipun harus diakui bahwa pada abad mula-mula dalam sejarah gereja tidak ada paham amilenialisme yang sempurna, namun ada unsur-unsur kecil dari amilenialisme. ${ }^{31}$

Tradisi ini kemudian berkembang secara pesat dua ratus tahun kemudian setelah Augustinus. Tradisi ini dilanjutkan oleh gereja, baik dalam gereja Katolik maupun Protestan. Kebangkitan besar lainnya dari amilenialisme ialah pada abad 20. Kebangkitan ini disebabkan postmilenialisme merosot drastis, yaitu karena kegagalan pandangan eskatologi terhadap realita yang terjadi. Kegagalan ini disebabkan karena pandangannya yang mengemukakan bahwa dunia semakin lama akan semakin baik menjelang kedatangan Kristus, karena di masa inilah "kerajaan seribu tahun" ini. Akan tetapi, perang dunia pertama dan kedua membuktikan bahwa postmilenialisme ini gagal.

Oleh karena itu, banyak dari pengikutnya merasa perlu untuk menelaah kembali dan memilih suatu pandangan

\footnotetext{
${ }^{30}$ John Walvoord, The Millennial Kingdom (Findley, Ohio: Dunham Publishing Company, 1959), 56.

${ }^{31}$ Ibid., 58
}

eskatologi yang baru bagi mereka. Kebanyakan dari mereka tidak memilih premilenialisme sebagai dasar eskatologi karena menggambarkan akan perpecahan yang begitu tajam dengan adanya pelbagai pandangan dan sikap yang saling menyerang di antara premilenialisme.

Di samping itu, pemilihan mereka akan amilenialisme karena ajaran ini mirip dengan ajaran postmilenialisme. Hal-hal yang mirip ini ialah:

(1) Kedatangan Kristus yang kedua akan memulai akhir zaman dan keadaan final (final state), baik dari orang beriman maupun orang yang tidak beriman. Hal ini berarti bahwa kedatangan yang kedua itu akan diikuti secara langsung oleh kebangkitan, penghakiman semua umat manusia dan pengiriman mereka pada tempat yang kekal. Peristiwa-peristiwa ini akan terjadi secara cepat, tanpa ada waktu interval yang cukup.

(2) Kedua pandangan eskatologi ini sama-sama menyakini bahwa masa seribu tahun dalam Wahyu 20 lebih bersifat simbolis daripada harafiah.

(3) Dua kebangkitan pada Wahyu 20 tidak memerlukan milenium di antaranya. Tetapi berlangsung secara bersama-sama ${ }^{32}$. Berdasarkan alasan-alasan inilah, sebagian besar penganut postmilenialisme kemudian cenderung memilih amilenialisme.

Pada saat ini, postmilenialisme kini terbagi atas dua pandangan yaitu a). Kebangkitan postmilenialisme (Revivalist Postmillenialism) yang mengemukakan bahwa millenium melambangkan periode waktu panjang dan tidak diketahui, yang ditandai dengan kebangkitan umat Kristiani. Kebangkitan ini ditandai dengan penginjilan yang berhasil ke seluruh dunia. Setelah penginjilan berhasil, Yesus akan datang yang kedua kalinya. Sebenarnya pandangan ini sulit dibedakan dengan

\footnotetext{
${ }^{32}$ Erickson, Pandangan Kontemporer dalam Eskatologi, 92.
} 
amilenialisme. Dengan demikian, orangorang yang mengaku mengikuti kebangkitan postmilenialisme sebenarnya orang-orang dari amilenial.

b). Rekonstrusi postmilenialisme (Reconstructionist Postmillenialis) yang mengemukakan bahwa gereja akan berkembang dalam pengaruhnya melalui penginjilan yang berhasil dan pengembangan. Pada akhirnya, akan didirikan Kerajaan Allah selama 1000 tahun (bisa harafiah ataupun kiasan) yang diikuti dengan kedatangan Kristus yang kedua kalinya. Pandangan ini masih dipertahankan oleh beberapa orang dari postmilenialisme, meskipun pandangan ini sudah banyak ditinggalkan orang lain.

\section{SISTEM HERMENEUTIKA}

Tokoh-tokoh teologi perjanjian, secara umum, tidak jauh berbeda dengan dispensasionalisme dalam menafsirkan Alkitab yaitu dengan menggunakan metode literal, grammatikal dan historikal. Kendati demikian, ada beberapa perbedaan konsep atau presupposisi (pandangan awal) dalam menafsirkan Alkitab.

Perbedaan-perbedaan inilah yang memengaruhi akan pandangan eskatologi (akhir zaman), ekklesiologi (gereja) dan soteriologi (keselamatan) di antara dispensasionalisme dan teologi kovenan.

Perbedaan-perbedaan ini ada tiga bentuk yaitu:

(1). Tokoh dari teologi perjanjian menafsirkan Perjanjian Lama (PL) dalam terang Perjanjian Baru (PB). Oleh karena itu, janji-janji kepada Israel dalam PL sebenarnya sedang dipenuhi dan ditujukan untuk gereja. Dispensasionalisme mengatakan bahwa PB tidak menafsirkan PL dan nubuatan PL mengenai Israel secara

\footnotetext{
${ }^{33}$ C.H. Giblin, The Book of Revelation (Collegeville:Liturgical, 1991), 304.

${ }^{34}$ T.F Glasson, Jewish Symbols in the Greco Roman World (Princeton: Princeton University, 1998), 401. ${ }^{35} \mathrm{P}$. Mauro, The Patmos Visions: A Study of the Apocalypse (Boston: Hamilton, 1945), 193.
}

literal akan dipenuhi secara khusus dalam Kerajaan Seribu Tahun. ${ }^{33}$

(2). Teologi perjanjian mengakui adanya gereja baik di dalam PL dan PB. Dispensasionalisme mengatakan bahwa gereja tidak ada dalam PL. Gereja ada ketika didirikan oleh Yesus dan berjalan ketika hari pentakosta dalam Kisah Para Rasul 2. Di samping itu, dispensasionalisme membuat perbedaan antara Israel dengan gereja. $^{34}$

(3). Dispensasionalisme mengemukakan bahwa Allah menyiapkan dua metode keselamatan yaitu untuk Israel dan gereja. Akan tetapi, teologi perjanjian hanya mengakui bahwa Allah menyiapkan satu metode keselamatan yaitu untuk gereja atau "Israel rohani" dari semenjak PL hingga PB. ${ }^{35}$

(4) Tokoh-tokoh dari teologi perjanjian menafsirkan sesuatu secara alegoris, simbolis maupun rohani, secara khusus atau bila berjumpa dengan hal-hal yang bersifat nubuatan. ${ }^{36}$ Metode alegoris atau pengrohanian maknanya itulah yang dipakai. Akan tetapi, ada beberapa syarat khusus dalam menggunakan metode alegoris oleh teolog kovenan yaitu: (a) Tatkala kalimat yang sedang dibahas, dengan jelas menggunakan bahasa figuratif. (b) Pada saat Perjanjian Baru tidak memberikan otoritas untuk menafsirkan ayat-ayat tertentu dalam nuasa literal. (c) Apabila prinsip penafsiran literal justru menghasilkan kontradiksi dengan kebenaran, prinsip dan pernyataan yang faktual yang berisikan dengan buku-buku yang tidak simbolis di dalam PB. ${ }^{37}$

Dengan demikian, tidak semua bagian dalam Alkitab yang ditafsirkan secara alegoris. Apabila ada nats-nats yang tidak dapat ditafsirkan secara literal, maka mereka menggunakan metode alegoris atau

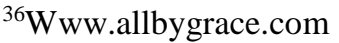

${ }^{37}$ J.R. Michaels, Interpreting the Book of Revelation (Grand Rapids: Baker, 1992), 256.
} 
pengrohanian makna. Akan tetapi, tatkala menafsirkan kitab-kitab nubuat, maka teologi perjanjian harus selalu menggunakan metode alegoris.

Seorang tokoh dari teologi perjanjian, Joel B. Green mengemukakan akan alasan penting yang menyebabkan penafsir tidak boleh menuntut penafsiran secara harafiah di dalam nubuat Alkitab: (1) Mengingat akan sifat dari bentuk-bentuk sastra yang digunakan untuk menyampaikan nubuatan, bahasa yang sering dipakai bersifat figuratif dan simbolis bahkan terkadang bersifat fantastis. Oleh karena itu, ketika Yesaya memproklamasikan, "Pada hari-hari yang akan datang, Yakub akan berakar, Israel akan berkembang dan bertunas dan memenuhi muka bumi dengan hasilnya" (27:6). Dengan demikian, pembaca tidak boleh membayangkan bahwa Yesaya mengharapkan pengharapan harafiah (secara botanis). Pembaca juga tidak perlu mencari-cari binatang harafiah seperti seekor singa bersayap elang (Dan. 7:4). Bilangan-bilangan pun sering digunakan secara simbolis. (2) Nubuatan Alkitab sering kali mengikut-sertakan pengajaran di samping prediksi-prediksi nubuatan. Beberapa penafsir, seperti Tim Lahaye secara kurang tepat, hanya memunculkan kesan bahwa nubuatan pada dasarnya merupakan pemberitahuan tentang peristiwa-peristiwa yang akan terjadi di masa depan. Nubuat, seharusnya, prediksi sekaligus pengajaran. Bila seseorang penafsir gagal mengakui sifat ganda dari nubuatan, maka ia telah kehilangan arah sejak awal. (3) Beberapa nubuat kelihatannya mengalami penggenapan lebih dari sekali. ${ }^{38}$ Yesaya 7:14 merupakan salah satu dari fenomena ini, "Sebab itu Tuhan sendirilah yang akan memberikan kepadamu sebuah pertanda: Sesungguhnya, seorang anak dara mengandung dan akan melahirkan seorang anak laki-laki, dan ia akan menamakan Dia Imanuel". Menurut

\footnotetext{
${ }^{38}$ Joel B. Green, Memahami Nubuatan (Jakarta:

Persekutuan Pembaca Alkitab, 2005), 31.
}

konteks ini ialah anak yang dijanjikan itu akan menjadi tanda Allah bagi raja Ahaz; tanda yang terjadi pada zaman Ahaz dan Yesaya. Akan tetapi, Matius mengutip nubuatan ini dan memproklamasikan bahwa penggenapan nas ini terjadi dalam peristiwa kelahiran Yesus (Mat. 1:23).

Berkenaan dengan Kitab Wahyu, kaum amilenialisme menafsirkan dengan mengambil prinsip-prinsip yang dapat diperoleh. Mereka mempercayai bahwa kitab Wahyu ini merupakan sebuah cerita alegoris mengenai penganiayaan pada abad pertama dan mewakili pertentangan antara kebaikan dengan kejahatan. Sistem penafsiran yang paling memuaskan bagi kaum amilenialisme, terhadap Kitab Wahyu, ialah pendekatan yang disebut sebagai paralelisme progresif, yaitu sebuah metode yang dengan cermat dipertahankan oleh William Hendriksen. ${ }^{39}$ Menurut pendekatan ini, Kitab Wahyu terbagi dalam tujuh bagian yang bersifat paralel satu dengan lainnya. Tiap-tiap paralel menggambarkan tentang sejarah gereja dan dunia mulai dari kedatangan Kristus yang pertama kali hingga kedatangan-Nya yang kedua kali.

Berkenaan dengan istilah amilenialisme, Hoekema menyatakan bahwa istilah tersebut bukanlah istilah yang tepat. Istilah ini memberikan kesan bahwa tokoh-tokoh dari teologi perjanjian tidak mempercayai adanya milenium atau orang-orang yang mengabaikan enam ayat pertama dari Wahyu 20, yaitu bagian yang berbicara mengenai pemerintahan milenium. Kedua tuduhan ini tidak benar. Meskipun memang harus diakui bahwa amilenialis tidak mempercayai adanya pemerintahan seribu tahun secara harafiah yang mengikuti kedatangan Kristus yang kedua kali. Jay. E. Adams mengusulkan bahwa istilah amilenialisme diganti dengan istilah milenialisme yang telah terwujud (realized milleniasm). Istilah Adams ini sebenarnya

\footnotetext{
${ }^{39}$ William Hendrikssen, Lebih Dari Pemenang (Jakarta: Momentum, 2007), 35.
} 
lebih mewakili pandangan orang-orang amilenialis. $^{40}$ Pada hakikatnya amilenialis percaya bahwa milenium yang disebutkan dalam Wahyu 20 tidak secara eksklusif menunjuk pada masa yang akan datang, melainkan sekarang ini sedang dalam proses untuk tergenapi.

Amilenialisme tidak mengakui akan adanya perbedaan antara Israel dengan gereja sampai saat ini. Mereka mengakui bahwa Israel telah diganti oleh gereja ketika pada hari pentakosta. Penggantian ini karena tiga penolakan Allah yang disebabkan oleh bangsa Israel sendiri. Penolakan pertama terhadap bangsa Israel tampak dari cerita pohon ara di dalam Matius 21:18-19. Pohon ara ini diyakini sebagai Israel dan telah dikutuk karena sama sekali tidak berbuah. Israel seharusnya menjadi berkat bagi bangsa-bangsa disekitarnya namun mereka gagal. Tidak hanya gagal menjadi berkat, tapi Israel pun ikut serta dan jatuh ke dalam perzinahan rohani. Kegagalan ini terjadi cukup banyak di dalam sepanjang sejarah Israel. Penolakan kedua terhadap bangsa Israel karena menolak dan tidak percaya kepada Yesus. Matius 21:42-43 menyatakan bahwa batu (Yesus) yang telah dibuang oleh tukang-tukang bangunan (Israel) akan menjadi batu penjuru. Hukuman yang akan diterima oleh bangsa Israel ialah kerajaan Allah akan diambil dari mereka dan akan diberikan kepada suatu bangsa yang baru yaitu gereja. Dengan demikian, penolakan kepada bangsa Israel karena menolak Mesias yang dijanjikan. Penolakan yang ketiga terhadap Israel ialah karena telah menyalibkan Anak Allah dan Mesias yang dinantikan itu. Ini merupakan kejahatan yang sangat kejam ditujukan kepada Allah oleh Israel. Pelbagai alasan inilah Israel telah ditolak oleh Allah. ${ }^{41}$

\footnotetext{
${ }^{40}$ Jay Adams, The Time is at Hand (Philadelphia: Presbyterian and Reformed, 1970), 7-11.

${ }^{41} \mathrm{~A}$. Vanhoye, Old Testament Priests and the New Priest according to the New Testament (Petersham: St. Bede's, 1986), 423.
}

Namun, Allah sekarang menggenapi tujuan-tujuannya di dalam gereja. Beberapa teolog, seperti dari kaum dispensasionalis, kemudian mempertanyakan akan janji-janji Allah yang belum digenapi bagi umat Israel. Tidak mungkin Israel ditolak apabila Allah belum selesai dan menggenapi segala janji terhadap Israel. kaum amilenialisme mengakui bahwa ada dua janji yang diberikan kepada Israel yaitu bersifat fisik dan rohani. Janji bersifat fisik semuanya telah dipenuhi oleh Allah. Namun, bila ada yang tidak terpenuhi itu semata-mata karena kegagalan Israel dalam menaati Allah. Janji yang bersifat spiritual akan digenapi di dalam gereja. Akan tetapi, kaum amilenialisme kemudian memberikan jawaban atas pelbagai keberatan ini. Allah sebenarnya telah memenuhi janji-Nya kepada Israel secara nasional ataupun kerajaan pada zaman Perjanjian Lama, secara khusus pada dinasti Daud dan Salomo. ${ }^{42}$ Janji tanah, contohnya, juga telah dipenuhi yaitu dalam Ulangan 1:8, Yosua 11:23; 21:41-45. Janji tanah ini telah dipenuhi dalam kepemimpinan Yosua yakni sekitar 600 tahun setelah janji tersebut diberikan kepada Abraham. "Lalu Yosua mengambil seluruh tanah itu, berdasarkan kepada titah Allah kepada Musa; dan Yosua memberikan itu untuk warisan kepada umat Israel berdasarkan suku-suku yang ada" (Yos. 11:23). Nats ini dikutip dari perkataan Allah kepada Musa di dalam Ulangan 1:8, "Ketahuilah, Aku telah menyerahkan negeri itu kepadamu; masukilah, dudukilah negeri yang dijanjikan TUHAN dengan sumpah kepada nenek moyangmu, yakni Abraham, Ishak dan Yakub, untuk memberikannya kepada mereka dan kepada keturunannya". Ini merupakan peneguhan kembali akan janji Tuhan kepada bangsa Israel mengenai tanah. Akan tetapi, nats berikut ini merupakan penggenapan dari janji Allah

\footnotetext{
${ }^{42}$ N.T Wright, The Climax of the Covenant (Minneapolis: Fortress, 1992), 187.
} 
yaitu, "seluruhnya kota-kota orang Lewi di tengah-tengah milik orang Israel ada empat puluh delapan kota dengan tanah-tanah penggembalaannya.Kota-kota itu masingmasing ada tanah-tanah penggembalaannya di sekelilingnya, demikianlah kota-kota tadi seluruhnya. Jadi seluruh negeri itu diberikan TUHAN kepada orang Israel, yakni negeri yang dijanjikan-Nya dengan bersumpah untuk diberikan kepada nenek moyang mereka. ${ }^{43}$ Mereka menduduki negeri itu dan menetap di sana. Dan TUHAN mengaruniakan kepada mereka keamanan ke segala penjuru, tepat seperti yang dijanjikan-Nya dengan bersumpah kepada nenek moyang mereka. Tidak ada seorangpun dari semua musuhnya yang tahan berdiri menghadapi mereka; semua musuhnya diserahkan TUHAN kepada mereka. Dari segala yang baik yang dijanjikan TUHAN kepada kaum Israel, tidak ada yang tidak dipenuhi; semuanya terpenuhi" (Yosua 21:41-45). Meskipun pada kenyataan kelak, Israel tidak taat (Neh. 9:26), bersahabat dengan penyembahan orang kafir dan berpaling dari Allah. Akan tetapi, hal ini tidaklah mengubah kenyataan di mana mereka akan mewarisi dan memerintah seluruh tanah (Yos. 11:23). Menurut kaum amilenialisme, janji tanah ini bersifat kondisional. Apabila mereka taat, tanah akan menjadi milik mereka. Begitu pula sebaliknya.

Janji lainnya ialah Israel akan dibebaskan dari pembuangan, kembali ke tanah mereka untuk membangun kembali bait suci, tata-keagamaan dan lain sebagainya. Kaum amilenialisme mengemukakan bahwa semua janji ini telah digenapi pada pemerintahan Persia di mana raja Koresh mengizinkan beberapa orang Yahudi untuk kembali pulang ke Yerusalem untuk mendirikan kembali Bait Allah (Ez. $1: 1-5) .{ }^{44}$

Janji ini persis digenapi seperti yang dikatakan oleh nabi Yeremia. "Sebab

${ }^{43}$ Ibid., 196. beginilah firman TUHAN: Apabila telah genap tujuh puluh tahun bagi Babel, barulah Aku memperhatikan kamu. Aku akan menepati janji-Ku itu kepadamu dengan mengembalikan kamu ke tempat ini. Sebab $\mathrm{Aku}$ ini mengetahui rancangan-rancangan apa yang ada pada-Ku mengenai kamu, demikianlah firman TUHAN, yaitu rancangan damai sejahtera dan bukan rancangan kecelakaan, untuk memberikan kepadamu hari depan yang penuh harapan. Dan apabila kamu berseru dan datang untuk berdoa kepada-Ku, maka Aku akan mendengarkan kamu; apabila kamu mencari Aku, kamu akan menemukan Aku; apabila kamu menanyakan Aku dengan segenap hati, Aku akan memberi kamu menemukan Aku, demikianlah firman TUHAN, dan Aku akan memulihkan keadaanmu dan akan mengumpulkan kamu dari antara segala bangsa dan dari segala tempat ke mana kamu telah Kuceraiberaikan, demikianlah firman TUHAN, dan Aku akan mengembalikan kamu ke tempat yang dari mana Aku telah membuang kamu". Yeremia telah menubuatkan (626 SM) bahwa Israel dibuang dan dijajah oleh bangsa asing. Namun, setelah tujuh puluh tahun Israel akan kembali ke Palestina. Yerusalem jatuh pada $586 \mathrm{SM}$ di mana pembuangan terdiri dari 3 gelombang. Gelombang pertama pada tahu 606 SM dan keputusan raja Koresh datang pada tahun 537-536. Hal ini menandakan bahwa nubuatan 70 tahun dari Yeremia secara harafiah sungguh digenapi. Sekembalinya dari pembuangan, Israel membangun kembali Bait Allah yang dimulai pada tahun 536 SM. Ini merupakan penggenapan dari sebagian janji Allah yang lain bagi Israel. Berbagai halangan kemudian mematahkan semangat mereka dan tidak melanjutkan pembangunan Bait Allah. Akan tetapi, Allah kemudian menggerakkan beberapa orang untuk kembali memulai pembangunan, yaitu Hagai dan Zakharia.

\footnotetext{
${ }^{44}$ M. Silva, Biblical Words and Their Meaning (Grand Rapids: Zondervan, 1983), 267.
} 
Empat tahun kemudian, 516 SM, pembangunan kembali Bait Suci selesai. Dengan demikian, tokoh-tokoh dari teologi perjanjian mengemukakan bahwa secara harafiah dan historis nubuat mengenai Israel telah dipenuhi dengan sempurna. ${ }^{45}$ Tidak hanya itu, janji pemulihan pun telah diberikan dalam Yeremia 2:10-14. Namun harus diakui bahwa ada beberapa janji Allah yang tidak "terpenuhi" yang dikarenakan pemberontakan Israel kepada-Nya.

Kaum amilenialisme beranggapan bahwa semua janji Allah kepada bangsa Israel bersifat kondisional meskipun tidak secara eksplisit disebutkan. Janji kondisional ini meliputi akan ketaatan, kesetiaan, sunat dan penerimaan Yesus sebagai Mesias pada kedatangan-Nya yang pertama. Kaum amilenialisme memakai kisah Abraham sebagai contoh.

Dalam Kejadian 15:6, Abraham percaya kepada Allah dan iman ini kemudian diperhitungkan sebagai kebenaran. Dengan kata lain, syarat bagi kebenaran ialah percaya. Kejadian 26:5 mengemukakan bahwa Allah memperbaharui perjanjian dengan Ishak karena Abraham taat kepada suara Tuhan dan memegang akan tuntutan-Nya. Kata "karena" merupakan suatu persyaratan antara Allah dengan Abraham maupun Israel. ${ }^{46}$ Allah tidak salah atau gagal tatkala janji-Nya tidak terpenuhi karena ketidaksetiaan Israel yang mengakibatkan batalnya janji tersebut. Ini merupakan perjanjian yang tak bersyarat.

Di samping itu, Allah sedang menjanjikan suatu umat, yaitu Israel rohani yang sedang dipenuhi melalui gereja baik orang-orang kafir maupun orang Israel itu sendiri. Dengan demikian, segenap janji secara spiritual akan digenapi di dalam gereja yang terdiri baik orang Yahudi

\footnotetext{
${ }^{45}$ E.C Selwyn, The Christian Prophets and the Prophetic Apocalypse (New York: Macmillan, 1990), 416.

${ }^{46}$ J.M Scott, Restoration of Israel (Downers Grove: InterVarsity, 1993), 796-805.
}

maupun orang kafir. Dengan kata lain, setiap janji untuk Israel sedang dilimpahkan kepada gereja karena Israel telah ditolak dan diganti oleh gereja. Tidak ada rencana untuk Israel lagi karena hanya ada satu umat saja yakni gereja. ${ }^{47}$ Inilah yang menjadi dasar dari segala pandangan teologis dari teologi perjanjian. PL, janji-janji Allah dan Kitab Wahyu harus dilihat dari perspektif gereja bukan Israel.

Kaum amilenialisme juga meyakini bahwa gereja sudah ada di dalam seluruh Perjanjian Lama. Paulus, contohnya, memakai gereja yang mengarah kepada Israel (Gal. 6:16). Di samping itu, sisa-sisa orang Israel di dalam PL dikatakan sebagai gereja (Kis. 7:38). Gereja sudah ada di dalam PL dengan pemilihan bangsa Israel menjadi umat Allah.

Bahkan lebih jauh lagi, penganut amilenialisme percaya bahwa gereja sudah ada ketika di taman Eden. Keberadaan gereja ini dimulai dari pemikiran Allah sebelum menciptakan dunia dengan pemberian Yesus kepada umat manusia kelak untuk menebus dan mengalahkan Iblis (Kej. 3:15). Dengan demikian, kaum amilenialisme mempercayai bahwa gereja hadir dalam segala zaman yaitu di masa lalu, masa kini dan masa yang akan datang. Bagi mereka, gereja dan Israel (zaman PL) hanyalah pertukaran istilah saja yang sebenarnya memiliki makna yang sama yaitu umat milik Tuhan. ${ }^{48}$ Namun ada perbedaan aspek, yaitu di masa lalu, Allah memilih Israel yang sedang berada di dalam padang gurun sebagai gereja. Masa kini dimengerti dengan pemilihan sisa-sisa Israel dan orang kafir yang percaya kepada Kristus sebagai milik-Nya. Masa depan yaitu ketika Yesus datang yang kedua kali, gereja sudah disempurnakan dan akan

\footnotetext{
${ }^{47}$ W. E. Cox, The New Covenant Israel (Philadelphia: Presbyterian and Reformed Publishing Company, 1964), 78.

${ }^{48}$ Oswald T. Allis, Prophecy and The Church (Philadelphia: Presbyterian and Reformed Publishing Co., 1945), 128.
} 
memerintah bersama-sama dengan Kristus di dalam bumi dan langit yang baru.

Amilenialis menafsirkan milenium dalam Wahyu 20:4-6 sebagai pemerintahan oleh jiwa orang-orang percaya yang telah meninggal dan yang sekarang ini bersamasama dengan Kristus di Sorga. Mereka memahami "diikatnya setan" sebagaimana disebutkan dalam tiga ayat pertama dari pasal ini sebagai periode waktu antara kedatangan Kristus yang pertama dan kedua. Dengan kata lain, pemerintahan seribu tahun dalam Wahyu 20:4-6 berlangsung sebelum kedatangan Kristus yang kedua.

Hal ini didasarkan pada fakta bahwa penghakiman seribu tahun yang disebutkan 20:11-15 dilukiskan sebagi peristiwa yang terjadi sesudah masa pemerintahan seribu tahun. Bukan hanya di dalam Kitab Wahyu, di seluruh bagian Perjanjian Baru lainnya juga menyatakan bahwa penghakiman akhir senantiasa dikaitkan dengan kedatangan Kristus yang kedua kali. ${ }^{49}$

Periode ini akan segera berakhir setelah Kristus datang kembali setelah pemerintahan milenium sorgawi, bukan di dunia. Memang harus diakui bahwa Wahyu 20 sering kali menimbulkan kontroversi dalam penafsiran, "dan mereka hidup kembali dan memerintah sebagai raja bersama-sama dengan Kristus untuk masa seribu tahun". Penafsir premilenialisme, baik dispensasionlis maupun nondispensasionalis, memahami kalimat tersebut sebagai sebuah gambaran harafiah yaitu peristiwa kebangkitan fisik dari kematian. Oleh sebab itu, melalui ayat ini mereka memperoleh alasan untuk mengajarkan tentang pemerintahan Kristus di bumi selama seribu tahun segera sesudah kedatangan-Nya yang kedua kali. Namun, menurut kaum amileniaslisme, tafsiran ini tidaklah tepat. Kata Yunani yang

\footnotetext{
${ }^{49}$ Matius 16:27; 25:31-32; Yudas 14-15; dan 2

Tesalonika 1:7-10.

${ }^{50} \mathrm{~J}$. W. Mealy, After the Thousand Years (Sheffield: JSOT, 1992), 522.
}

diterjemahkan sebagai "hidup kembali" (ezesan), memang dapat menunjuk kepada kebangkitan fisik (Mat. 9:18; Rm. 14:9; 2 Kor. 13:4; Why. 2:8). ${ }^{50}$

Kendati demikian, pengertian kata tersebut tidak sesuai dengan ayat dalam Wahyu 20. Hal ini dikarenakan kebangkitan tubuh dari kematian, baru saja dibicarakan oleh Yohanes pada ayat 11-13 sebagai kebangkitan yang sifatnya berbeda dari kebangkitan yang sedang dibicarakan di ayat 4 dan 5 . Petunjuk untuk memahami ayat ini telah diberikan pada ayat 4a. Di sini Yohanes berkata, "Lalu aku melihat takhtatakhta dan orang-orang yang duduk di atas takhta-takhta sorgawi tersebut merupakan jiwa-jiwa orang yang telah mati yaitu orangorang percaya yang telah setia kepada Kristus dan khususnya, para martir yang telah membuktikan iman mereka melalui kehidupan mereka. Ini merupakan kumpulan orang percaya yang Yohanes telah lihat "hidup kembali dan memerintah bersama-sama dengan Kristus". Meskipun orang-orang percaya ini telah mati, namun Yohanes melihat mereka hidup bukan dalam pengertian fisik tetapi dalam arti bahwa mereka sedang menikmati kehidupan di Sorga di dalam persekutuan dengan Kristus. ${ }^{51}$

Dengan demikian, kata ezesan (dihidupkan atau hidup kembali), pada ayat 4, merupakan gambaran tentang fakta bahwa jiwa-jiwa orang percaya yang telah mati sekarang ini hidup bersama dengan Kristus di Sorga dan turut serta di dalam pemerintahan-Nya di dalam masa seribu tahun. Dengan kata lain, pemerintahan Kristus bersama dengan orang-orang percaya di masa seribu tahun bukanlah di bumi melainkan di Sorga.

Keadaan Iblis juga dijelaskan dalam 20:1-6. Dalam ayat-ayat ini dikatakan bahwa Iblis diikat selama seribu tahun dan

\footnotetext{
${ }^{51}$ Anthony Hoekema, Alkitab dan Akhir Zaman (Surabaya: Momentum, 2004), 241.
} 
kemudian dilemparkan ke dalam sebuah tempat yang disebut sebagai "jurang maut". Tujuan pengikatan ini adalah "supaya ia jangan lagi menyesatkan bangsa-bangsa sebelum berakhir masa seribu tahun itu". Teolog Kovenan mengartikan "seribu tahun" bukan secara harafiah, tetapi simbolis. White mengemukakan bahwa nomor keramat tujuh apabila digabungkan dengan nomor tiga yang juga keramat akan membentuk nomor kesempurnaan yang kudus, yaitu sepuluh. ${ }^{52}$ Oleh karena angka sepuluh mengandung arti "genap" dan karena seribu adalah sepuluh pangkat tiga, maka cukup masuk akal bila dipahami sebagai simbol bagi genapnya sebuah periode waktu yaitu sebuah periode waktu panjang yang tidak dapat ditentukan secara pasti.

Di samping itu, kaum amilenialisme mengartikan jurang maut sebagai arti figuratif, yaitu suatu kondisi di mana aktivitas Iblis sangat dibatasi selama seribu tahun. Akan tetapi, hal ini tidak berarti bahwa Iblis tidak dapat melakukan kejahatan apapun juga selama dirantai. Pernyataan Yohanes lebih mengarah kepada tindakan Iblis yang tidak dapat menyesatkan bangsa-bangsa sedemikian rupa sehingga dapat mencegah manusia untuk mengenal kebenaran Tuhan.

Bukti yang diberikan oleh kaum amilenialisme bahwa Iblis telah dirantai pada saat kedatangan Kristus yang pertama ialah ketika orang Farisi menuduh Yesus telah mengusir Iblis dengan kuasa penghulu setan. Akan tetapi, Yesus menjawab, "Bagaimanakah orang dapat memasuki rumah seorang yang kuat dan merampas harta bendanya apabila tidak diikatnya dahulu orang kuat itu?" (Mat.12:29).

Menarik bahwa kata yang dipakai Matius untuk menggambarkan diikatnya orang yang kuat adalah kata yang sama

${ }^{52}$ R.F White, The Millennial Kingdom (Missoula: Society of Biblical Literature, 1972), 384.

${ }^{53}$ A.W Wainwright, Mysterious Apocalypse: Interpreting the Book of Revelation (Nashville: Abinkon, 1993), 361. dipakai dalam Wahyu 20 untuk menggambarkan diikatnya Iblis (yaitu kata Yunani deo $).{ }^{53}$ Oleh karena itu, teolog kovenan mengatakan bahwa Yesus telah mengikat Iblis ketika Ia menang dalam puasa selama empat puluh hari, empat puluh malam di padang gurun dengan Ia menolak segala godaan Iblis. Bukti selanjutnya ialah tatkala ketujuh puluh murid kembali dari misi pemberitaan Injil, mereka berkata kepada Tuhan Yesus, "Tuhan, juga setansetan takluk kepada kami demi nama-Mu". Yesus menjawab, "Aku melihat Iblis jatuh seperti kilat dari langit” (Luk. 10:17-18).

Jelas bahwa kalimat Tuhan Yesus tersebut tidak dapat dimengerti secara harafiah sebagai jatuhnya Iblis dari sorga pada detik itu. Kalimat itu harus diartikan bahwa bagi Tuhan Yesus, pekerjaan para murid-Nya merupakan sebuah indikasi bahwa kerajaan Iblis telah dikalahkan bahwa pembatasan kuasa Iblis mulai diberlakukan. ${ }^{54}$

Melalui peristiwa ini, kaum amilenialisme melihat bahwa Kejatuhan Iblis atau diikatnya dikaitkan langsung dengan kegiatan pemberitaan Injil oleh murid-murid Tuhan Yesus. Bukti terakhir yang berbicara mengenai pembatasan kekuasaan Iblis ialah dengan pemberitaan Injil dalam Yohanes 12:31-32, "Sekarang berlangsung penghakiman atas dunia ini: sekarang juga penguasa dunia ini akan dilemparkan keluar dan Aku, apabila Aku ditinggikan dari bumi, Aku akan menarik semua orang datang kepada-Ku". Menarik bahwa kata kerja yang diterjemahkan sebagai "dilemparkan" Iblis di sini dikaitkan dengan fakta bahwa bukan hanya orang-orang Yahudi melainkan semua orang dari segala suku bangsa akan ditarik dan datang kepada Salib Kristus. ${ }^{55}$ Dengan demikian, bukti-bukti ini yang dipakai oleh teolog kovenan untuk menyangkal bahwa

\footnotetext{
${ }^{54}$ Ibid., 377.

${ }^{55}$ Robert G. Clouse, The Meaning of Millenium

(Downers Grove: Inter Varsity, 1977), 161.
} 
kerajaan seribu tahun merupakan suatu periode khusus yaitu setelah kedatangan Kristus yang kedua kalinya. Berikut ini merupakan bagan gambar mengenai pandangan seribu tahun dari beberapa pandangan eskatologi ${ }^{56}$ :

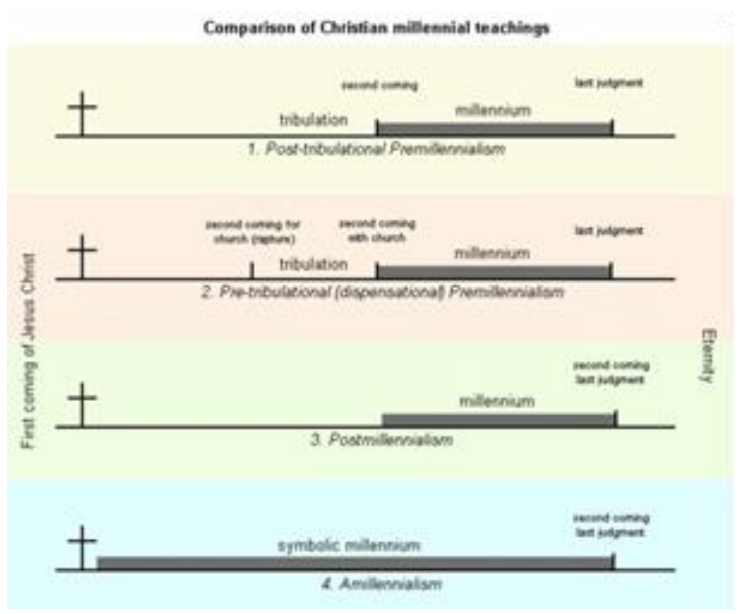

Lebih lanjut, amilenialis memegang keyakinan bahwa Kerajaan Allah sekarang ini telah hadir di dalam dunia dalam wujud pemerintahan Kristus atas umat-Nya, melalui Firman dan Roh Kudus. Namun pada saat yang bersamaan, amilenialis juga merupakan orang-orang yang sedang menantikan penyempurnaan Kerajaan Allah di masa yang akan datang, di dalam bumi yang baru.

Mereka menyadari bahwa meskipun memang Kristus telah menang dengan pasti atas dosa dan Iblis, namun kuasa Iblis akan tetap ada bersama-sama dengan Kerajaan Allah hingga akhir zaman.

Meskipun gereja telah menikmati banyak berkat-berkat eskatologi pada masa sekarang ini (eskatologi yang telah terwujud), gereja masih merindukan klimaks dari seluruh tanda zaman dan kedatangan Kristus yang kedua yang akan menghantar kita ke dalam kondisi final (eskatologi yang akan datang). ${ }^{57}$ Dengan kata lain, segala yang disebut sebagai "tanda-tanda zaman" telah berlangsung

\footnotetext{
${ }^{56}$ Www.covenanttheology.com/theopedia/pics

${ }^{57}$ Marcellus Kik, The Eschatology of Victory

(Philadelphia: Presbyterian and Reformed Co., 1971), 204.
}

sejak kedatangan Kristus yang pertama, dan akan terus memuncak hingga sebelum Kedatangan Kedua. Oleh karena itu, amilenialis menantikan digenapinya penyebaran Injil ke seluruh bangsa termasuk pertobatan jumlah yang penuh dari bangsa Israel, sebelum Kristus kembali. Mereka juga terus mewaspadai akan meningkatnya kesusahan, murtad dan munculnya pribadi antikristus sebelum Kedatangan Kedua.

Amilenialis memahami kedatangan Kristus yang kedua sebagai satu peristiwa tunggal dan bukan satu peristiwa dengan dua tahap di dalamnya. Amilenialis mengajarkan bahwa peristiwa-peristiwa tertentu harus terjadi terlebih dahulu sebelum kedatangan-Nya yang kedua. Dengan demikian, kedatangan Kristus tidak dapat disebut imminent yaitu Kristus dapat datang sewaktu-waktu. Tanda-tanda sebelum kedatangan Kristus yang kedua kali dapat dilihat sebagai berikut yaitu panggilan bagi orang-orang non Yahudi (Mat. 24:14; Mrk. 13:10; Rm. 11:25), yaitu bangsa-bangsa akan diinjili. Sebagian dari mereka akan percaya dan termasuk ke dalam "kepenuhan orang non-Yahudi". ${ }^{58}$

Pertobatan Israel atau yang disebut "semua orang Israel" dalam Roma 11:26 bukan berarti bangsa Israel secara harafiah melainkan sejumlah orang Israel pilihan. Kemurtadan yang besar dan peristiwa Tribulasi yang besar (Mat. 24:9-12, 21-24; Mrk. 13:9-22; Luk. 21:22-24).

Peristiwa-peristiwa ini memiliki penggenapan parsial dalam penghancuran Yerusalem tetapi juga memiliki penggenapan di masa yang akan datang. ${ }^{59}$ Pernyataan seorang antikristus yang akan datang. Unsur-unsur antikristus memang telah ada pada masa Paulus dan dalam sistem kepausan dari Roma, tetapi identitas antikristus pada akhirnya akan digenapi

\footnotetext{
${ }^{58}$ T.F Torrance, The Apocalypse of John (New Haven: Yale University, 1958), 506.

${ }^{59}$ Berkof, The Second Coming of Christ, 130.
} 
dalam sosok pribadi eskatologis.

Pribadi ini akan diwarnai dengan banyaknya tanda dan mujizat yang akan terjadi disertai dengan peperangan, nabinabi palsu dan tanda-tanda ajaib dari setan yang menakjubkan. Kristus akan datang pada saat "hari konsumasi", hari kiamat; namun tidak ada seorang pun yang tahu waktu kedatangan-Nya. Cara dari kedatangan-Nya akan bersifat pribadi, fisikal dan terlihat oleh mata (Kis. 1:11). Hal itu tidak boleh disejajarkan dengan kedatangan Roh Kudus pada hari Pentakosta. Amilenialis mengajarkan pula bahwa tujuan dari kembalinya Kristus adalah untuk "memperkenalkan masa yang akan datang, keadaan pada masa kekekalan". ${ }^{60}$ Hal ini akan terjadi pada waktu kebangkitan orang mati dan penghakiman terakhir.

Pada saat Kristus datang kembali, akan terjadi kebangkitan umum, bagi orangorang percaya yang masih hidup maupun tidak percaya. Hal ini terdapat di dalam bagian seperti Daniel 12:2; Yohanes 5:28,29; Kisah Para Rasul 24:15; Wahyu 20:13-15. Daniel 12:2 menyebutkan orang saleh dan orang fasik dalam pernyataan waktu yang sama, sebagaimana yang dinyatakan dalam Yohanes 5:282-29. Istilah "waktu" dalam Yohanes 5:28 tidak dapat digunakan untuk menunjuk pada perbedaan seribu tahun antara dua kebangkitan.

Pada Kisah Para Rasul 24:15, Paulus menggunakan pula istilah "tunggal" bagi kebangkitan untuk menjabarkan kebangkitan pada orang percaya maupun orang yang tidak percaya. Sedangkan dalam Wahyu 20:13-15, hal ini haruslah ditujukan untuk semua orang mati, bukan hanya orang yang tidak percaya, karena istilah "maut dan kerajaan maut menyerahkan orang-orang mati yang ada di dalamnya" harus menunjuk kepada semua orang. ${ }^{61}$ Dengan

\footnotetext{
${ }^{60}$ K.A Strand, Chiastic Structure and Some Motifs in the Book of Revelation (New York: Newville, 1983), 204.
}

demikian, kebangkitan orang percaya dan orang tidak percaya ini akan terjadi pada kedatangan Kristus yang kedua (1Kor. 15:23; Flp. 3:20-21; 1 Tes. 4:16) dan ini juga menunjuk pada "hari terakhir" atau "hari Tuhan".

Setelah kebangkitan, orang-orang percaya yang masih hidup pada saat Kristus kembali akan diubahkan dan dimuliakan. Kedua macam orang percaya ini, yaitu orang percaya yang dibangkitkan dan orang percaya yang diubahkan akan diangkat dan bertemu dengan Tuhan di awan-awan. Setelah "pengangkatan" orang-orang percaya ini, Kristus akan menyudahi kedatangan-Nya kembali dengan melaksanakan penghakiman terakhir. Penghakiman terakhir ini akan terjadi pada akhir zaman dan diasosiasikan dengan kedatangan Kristus yang kedua, kebangkitan semua orang dan inagurasi dari keadaan kekal.

Oleh karena itu, akan ada penghukuman umum karena tujuan dari penghakiman orang hidup dan menentukan setiap individu pada tujuan akhir mereka. Tiga tujuan yang berbeda untuk penghakiman terakhir ini yaitu untuk menyatakan kedaulatan dan kemuliaan Allah tentang tujuan akhir dari setiap orang. Penghakiman yang bertujuan untuk menyatakan derajat dari upah dan derajat dari penghukuman yang akan diterima oleh setiap orang.

Penghakiman untuk melaksanakan penghakiman Allah pada setiap orang. Allah sekarang akan menunjukkan kepada setiap orang akan tempat yang akan dilalui dalam kekekalan. ${ }^{62}$ Oleh karena itu, orangorang yang tidak percaya akan dicampakkan ke dalam hukuman kekal. Sedangkan bagi mereka yang percaya akan menikmati segala berkat di dalam langit dan bumi yang baru selama-lamanya.

\footnotetext{
${ }^{61}$ K.A Strand, Chiastic Structure and Some Motifs in the Book of Revelation, 250.

${ }^{62}$ Erickson, Pandangan Kontemporer dalam

Eskatologi, 102.
} 
Isi dari penghakiman terakhir ini akan meliputi "perbuatan, kata-kata dan pikiran" dari seseorang. Penghakiman akan perbuatan seseorang dapat dilihat dari Matius 25:35-40; perkataan yang sia-sia akan dihakimi (Mat.12:36) dan segala pikiran akan dinyatakan (1 Kor. 4:5). Standar dari penghakiman ini adalah wahyu Allah. ${ }^{63}$ Mereka yang menerima wahyu dari PL akan dihakimi berdasarkan wahyu tersebut begitu pula dengan mereka yang menerima kebenaran dari wahyu PB (Mat. 11:20-22). Akan tetapi, bagi mereka yang tidak menerima kebenaran wahyu PL dan PB akan dihakimi berdasarkan terang yang mereka terima.

Akhir zaman kemudian akan memunculkan "regenerasi" (Mat. 19:28) yang disebut sebagai pembaharuan dari ciptaan yang sekarang. Ini merupakan tempat yang disebut dalam Alkitab sebagai surga, tempat tinggal yang kekal bagi orang percaya dengan Allah Tritunggal. Di sinilah "mereka akan melihat Allah dalam Kristus Yesus secara muka dengan muka dan kemudian akan menemukan kepuasan yang penuh di dalam Dia, bersukacita dan memuliakan-Nya". ${ }^{64}$ Inilah pelbagai pandangan eskatologi yang dipegang oleh kaum amilenialisme secara khusus tatkala mendekati Kitab Wahyu.

Berikut ini merupakan kesimpulan dari pandangan amilenialisme yang dapat dilihat dari gambar di bawah ini ${ }^{65}$ :

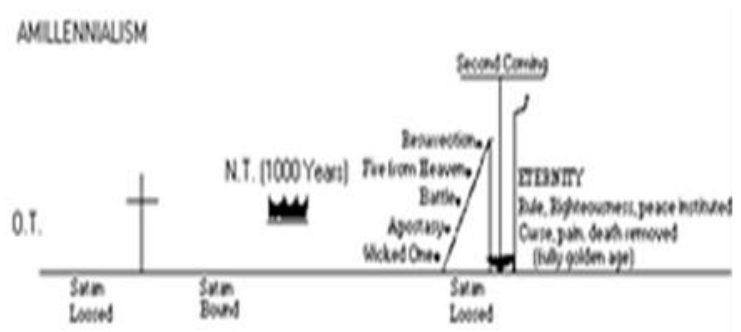

${ }^{63}$ A. Sperber, Judgement In Last Day (London: SCM, 1965), 335.

\section{KITAB WAHYU MENURUT AMILENIALISME}

Eksposisi Kitab Wahyu, menurut teolog kovenan, didasarkan pada metode paralelisme progresif yang terbagi menjadi tujuh bagian. Paralel yang pertama ialah pasal 1-3. Di bagian ini digambarkan bagaimana Yohanes melihat Kristus yang telah dibangkitkan dan dimuliakan sedang berjalan di tengah-tengah ketujuh kaki dian emas. Di dalam ketaatannya kepada Kristus, Yohanes kemudian menulis surat yang dikirimkan kepada ketujuh gereja di Asia Kecil. ${ }^{66}$ Meskipun Kitab Wahyu ditujukan kepada gereja abad pertama dan di dalam beritanya terdapat keterangan tentang pelbagai peristiwa yang terjadi pada masa tersebut, kitab ini juga dimaksudkan untuk gereja di sepanjang zaman. Oleh karena itu, kebenaran yang terkandung di dalamnya masih relevan untuk masa ini.

Paralel kedua, pasal 4-7, merupakan suatu penglihatan tentang tujuh meterai. Di bagian ini, Yohanes terangkat ke Sorga dan menyaksikan Tuhan duduk di takhta-Nya yang berkilauan. Kemudian, ia melihat Anak Domba yang telah disembelih menerima gulungan kitab yang termeterai dengan tujuh meterai dari tangan Dia yang duduk di takhta tersebut. Peristiwa ini mengindikasikan bahwa Kristus telah meraih kemenangan secara mutlak atas kuasa-kuasa kejahatan dan itu sebabnya Ia pantas membuka tujuh meterai tersebut. Ketujuh meterai itu satu demi satu dibuka dan masing-masing menggambarkan berbagai penghakiman ilahi atas dunia. Di dalam penglihatan ini, kaum amilenialisme melihat bahwa gereja mengalami pelbagai kesulitan dan penganiayaan meskipun latar belakang dari semua ini ialah kemenangan Kristus. Paralel yang kedua ini kemudian diakhiri dengan petunjuk bahwa setiap akhir

\footnotetext{
${ }^{64}$ Cox, Biblical Studies in Final Things

(Philadelphia: Presbyterian and Reformed, 1967), 98.

${ }^{65}$ Www.wikipedia.org/wiki/covenanttheology/pic

${ }^{66}$ Hoekema, Alkitab dan Akhir Zaman, 168.
} 
zaman telah tiba. Petunjuk ini merupakan bentuk penghakiman akhir pada penutupan sejarah dan kondisi akhir yang penuh berkat bagi umat Allah. ${ }^{67}$

Wahyu 6:15-17 tertulis tentang penghakiman akhir, "Dan raja-raja di bumi dan pembesar-pembesar serta perwiraperwira dan orang-orang kaya serta orangorang berkuasa, dan semua budak serta orang merdeka bersembunyi ke dalam guagua dan celah-celah batu karang di gunung. Dan mereka berkata kepada gunung-gunung dan kepada batu-batu karang itu: "Runtuhlah menimpa kami dan sembunyikanlah kami terhadap Dia yang duduk di atas takhta dan terhadap murka Anak Domba itu. Sebab sudah tiba hari besar murka mereka dan siapakah yang dapat bertahan?"

Akan tetapi, dalam Wahyu 7:15-17 tertulis akan penggambaran tentang kemuliaan bagi mereka yang telah keluar dari kesusahan besar, "Karena itu mereka berdiri di hadapan takhta Allah dan melayani Dia siang malam di Bait SuciNya. Dan Ia yang duduk di atas takhta itu akan membentangkan kemah-Nya di atas mereka. Mereka tidak akan menderita lapar dan dahaga lagi, dan matahari atau panas terik tidak akan menimpa mereka lagi. Sebab Anak Domba yang di tengah-tengah takhta itu, akan menggembalakan mereka dan akan menuntun mereka ke mata air kehidupan. Dan Allah akan menghapus segala air mata dari mata mereka." Dengan demikian, paralel yang kedua ini berisi mengenai penghakiman dan penghukuman Allah atas dunia.

Paralel ketiga, pasal 8-11, melukiskan tentang ketujuh sangkakala penghakiman. Di dalam penglihatan ini, kaum amilenialisme mendapati bahwa gereja dilindungi dan meraih kemenangan. Bagian ketiga ini berakhir dengan penggambaran akan penghakiman akhir, "Dan semua bangsa telah marah, tetapi amarah-Mu telah datang dan saat bagi orang-orang mati untuk dihakimi dan untuk memberi upah kepada hamba-hamba-Mu, nabi-nabi dan orangorang kudus dan kepada mereka yang takut akan nama-Mu, kepada orang-orang kecil dan orang-orang besar dan untuk membinasakan barangsiapa yang membinasakan bumi" (11:8). ${ }^{68}$ Paralel yang ketiga ini lebih terperinci mengenai murka Allah yang dilimpahkan bagi dunia, kecuali gereja.

Paralel keempat, pasal 12-14, diawali dengan penglihatan tentang perempuan yang mengandung dan melahirkan seorang anak sementara naga itu menanti untuk menelan anak itu, apabila anak itu dilahirkan. Ini merupakan sebuah penglihatan yang jelas melambangkan akan kelahiran Kristus. Bagian selanjutnya dari paralel ini menggambarkan pertentangan yang terus berlanjut antara naga itu (Iblis) dan gereja. Di bagian ini diperkenalkan juga dua macam binatang yang membantu naga ini, yaitu binatang yang keluar dari dalam laut dan binatang yang keluar dari dalam bumi.

Bagian ini berakhir pula dengan penggambaran secara figuratif tentang Kristus yang datang untuk menghakimi dunia, "Dan aku melihat: sesungguhnya, ada suatu awan putih, dan di atas awan itu duduk seorang seperti Anak Manusia dengan sebuah mahkota emas di atas kepala-Nya dan sebilah sabit tajam di tangan-Nya. Maka keluarlah seorang malaikat lain dari Bait Suci; dan ia berseru dengan suara nyaring kepada Dia yang duduk di atas awan itu: Ayunkanlah sabit$\mathrm{Mu}$ itu dan tuailah, karena sudah tiba saatnya untuk menuai; sebab tuaian di bumi sudah masak." (14:14-15). ${ }^{69}$ Dengan demikian, paralel keempat ini berisi mengenai perseteruan antara umat Allah dengan Iblis pada masa kerajaan seribu tahun.Paralel kelima, pasal 15-16, menggambarkan ketujuh cawan murka

\footnotetext{
${ }^{67}$ Hendrikssen, Lebih Dari Pemenang, 60.

${ }^{68}$ Hoekema, Alkitab dan Akhir Zaman, 172.
}

${ }^{69}$ Hoekema, Alkitab dan Akhir Zaman, 174. 
Allah yaitu penyingkapan murka Allah yang berakhir bagi mereka yang tidak mau bertobat. Paralel ini juga diakhiri dengan berita tentang penghakiman akhir, "Lalu terbelahlah kota besar itu menjadi tiga bagian dan runtuhlah kota-kota bangsabangsa yang tidak mengenal Allah. Maka teringatlah Allah akan Babel yang besar itu untuk memberikan kepadanya cawan yang penuh dengan anggur kegeraman murkaNya. Dan semua pulau hilang lenyap, dan tidak ditemukan lagi gunung-gunung. Dan hujan es besar, seberat seratus pon, jatuh dari langit menimpa manusia, dan manusia menghujat Allah karena malapetaka hujan es itu, sebab malapetaka itu sangat dahsyat" (16:19-20). ${ }^{70}$ Paralel kelima berisi tentang penghakiman akhir Allah bagi mereka yang masih tidak mau bertobat.

Paralel keenam, pasal 17-19, melukiskan tentang kejatuhan Babel dan binatang itu. Babel merupakan simbol bagi kota duniawi - gambaran bagi kehidupan sekuler dan tanpa Allah serta musuh Kerajaan Allah. Di bagian akhir pasal 19 tertulis tentang kejatuhan dua penolong naga itu, binatang yang keluar dari dalam laut dan binatang yang keluar dari dalam bumi. Pasal 19:11 kemudian berbicara tentang kedatangan Kristus yang kedua kali, "Lalu aku melihat sorga terbuka: sesungguhnya, ada seekor kuda putih; dan Ia yang menungganginya bernama: "Yang Setia dan Yang Benar", Ia menghakimi dan berperang dengan adil".

Pada ayat berikutnya berbicara mengenai penghakiman akhir atas kedua penolong naga itu, "Dan aku melihat binatang itu dan raja-raja di bumi serta tentara-tentara mereka telah berkumpul untuk melakukan peperangan melawan Penunggang kuda itu dan tentara-Nya. Maka tertangkaplah binatang itu dan bersama-sama dengan dia nabi palsu, yang telah mengadakan tanda-tanda di depan matanya, dan dengan demikian ia

\footnotetext{
${ }^{70}$ Hendrikssen, Lebih Dari Pemenang, 64.

${ }^{71}$ Hendrikssen, Lebih Dari Pemenang, 66.
}

menyesatkan mereka yang telah menerima tanda dari binatang itu dan yang telah menyembah patungnya. Keduanya dilemparkan hidup-hidup ke dalam lautan api yang menyala-nyala oleh belerang" $(19: 19-20){ }^{71}$ Paralel keenam berisi mengenai peperangan Allah melawan naga disertai dengan kekalahan Iblis.

Paralel ketujuh, pasal 20-22, mengisahkan tentang kehancuran sang naga sehingga dengan demikian melengkapi penggambaran tentang kekalahan semua musuh Kristus. Penghakiman dan penghukuman akhir atas orang-orang berdosa yang dilukiskan pada akhir pasal 20, "Lalu aku melihat suatu takhta putih yang besar dan Dia, yang duduk di atasnya. Dari hadapan-Nya lenyaplah bumi dan langit dan tidak ditemukan lagi tempatnya. Dan aku melihat orang-orang mati, besar dan kecil, berdiri di depan takhta itu. Lalu dibuka semua kitab. Dan dibuka juga sebuah kitab lain, yaitu kitab kehidupan. Dan orang-orang mati dihakimi menurut perbuatan mereka, berdasarkan apa yang ada tertulis di dalam kitab-kitab itu. Lalu maut dan kerajaan maut itu dilemparkanlah ke dalam lautan api. Itulah kematian yang kedua: lautan api. Dan setiap orang yang tidak ditemukan namanya tertulis di dalam kitab kehidupan itu, ia dilemparkan ke dalam lautan api itu" (20:11-12, 14-15). ${ }^{72}$ Lebih lanjut, bagian ini melukiskan tentang kemenangan akhir Kristus dan gereja-Nya serta pembaharuan atas seluruh ciptaan yang disebut sebagai langit dan bumi yang baru.

Ketujuh bagian tersebut bersifat paralel satu dengan lainnya. Masing-masing bagian juga menyingkapkan akan progresivitas tertentu dalam proses eskatologi. Paralel yang terakhir, misalnya, membawa pembaca kepada masa depan yang lebih jauh ketimbang bagian lainnya. Meskipun penghakiman akhir telah dikumandangkan dalam Why. 1:7, namun

\footnotetext{
${ }^{72}$ Hoekema, Alkitab dan Akhir Zaman, 184.
} 
disebutkan juga secara singkat dalam 6:1217, tetapi tidak digambarkan secara rinci seperti dalam 20:11-15.

Demikian pula akan sukacita sorgawi yang akan dialami oleh orang-orang percaya di kehidupan yang akan datang dalam 7:15-17 baru pasal 21, pembaca akan mendapati gambaran yang lebih lengkap tentang kehidupan yang penuh dengan sukacita dalam bumi yang baru. $^{73}$ Inilah sebabnya penafsiran ini dinamakan paralelisme progresif, yaitu ada perkembangan eskatologi dalam tujuh paralel tersebut.

Meskipun kitab Wahyu terbagi atas tujuh bagian, namun tidak boleh hanya memperhatikan atau terfokus pada satu bagian saja tetapi hendaknya menghargai semua bagian dalam kitab Wahyu sebagai keseluruhan. Hoekema menyarankan agar kiranya kitab Wahyu dibaca sebagai penggambaran akan pergumulan Kristus dengan jemaat-Nya maupun pertentangan antara Kristus dengan Iblis. Pasal 1-11 merupakan pergumulan Kristus dengan jemaat-Nya di dalam bumi yang dianiaya oleh dunia. Namun, pada pasal 12-22, Hoekama menunjukkan bahwa pasal-pasal ini menunjukkan kedalaman spiritual dari pergumulan ini. Maksudnya ialah penganiayaan gereja oleh Iblis dan pengikut-pengikutnya. ${ }^{74}$ Namun di dalam pasal 20-22 menunjukkan akan penghakiman dan penghukuman dari Iblis dan pengikut-pengikutnya. Di samping itu, pasal-pasal ini juga menunjukkan akan kemenangan dan pemerintahan kekal Kristus.

\section{DAFTAR PUSTAKA}

[1] Adams, Jay. The Time is at Hand. Philadelphia: Presbyterian and Reformed.

[2] Allis, swald T. Prophecy and The Church. Philadelphia: Presbyterian and
Reformed Publishing Co., 1945.

[3] Bear, James E. Dispensationalism and the Covenant of Grace. Richmond: Union Seminary Review, 1938.

[4] Behm, Johanes. Berith, Theological Dictionary of The New Testament, Vol. III, ed.

[5] Berkof, The Second Coming of Christ. Grand Rapids: Wm. B. Eerdmans Publishing Company, 1953.

[6] Berkof, Louis. Summary of Christian Doctrine. Grand Rapids: Eerdmans, 1938.

[7] Berkhof, Louis. Systematic Theology. Grand Rapids: Wm. B. Eerdmans Publishing Co., 1941.

[8] Berkhof, Louis. Teologi Sistematika, Vol II (Jakarta: Lembaga Reformed Injili Indonesia, 1995.

[9] Bromiley, Geoffrey W. Historical Theology: An Introduction. Grand Rapids: Eerdmans, 1978.

[10] Buswell, J. Oliver. A Systematic Theology of Christian Religion Vol. II. Grand Rapids: Zondervan, 1962.

[11] Brown, Colin. Dictionary of New Testament Theology (Grand Rapids: Michigan, Zondervan Publishing House.

[12] Chia PS, Juanda J. Dispensasionalisme Sebagai Metode Dalam Memahami Alkitab. Journal KERUSSO. 2020 Mar 26;5(1):20-3 [13] Clouse, Robert G. The Meaning of Millenium. Downers Grove: Inter Varsity, 1977.

[14] Collins, George N.M."Covenant Theology," Baker's Dictionary of Theology. Grand Rapids: Baker Book House, 1960.

${ }^{73}$ Www.lgmarshall.org

${ }^{74}$ Hoekema, Alkitab dan Akhir Zaman, 189. 
[15] Cox, W. E. The New Covenant Israel. Philadelphia: Presbyterian and Reformed Publishing Company, 1964.

[16] Cox, William E. Amillennialism Today. New Jersey, Presbyterian and Reformed Publishing Co., 1977

[17] Cox, William E. Biblical Studies in Final Things. Philadelphia: Presbyterian and Reformed, 1967.

[18] Enns, Paul. The Moody Handbook of Theology. Malang: Seminari Alkitab Asia Tenggara, 2004.

[19] Erickson, Millard J. Pandangan Kontemporer dalam Eskatologi. Malang: Seminari Alkitab Asia Tenggara, 2004.

[20] Giblin, C.H. The Book of Revelation. Collegeville:Liturgical, 1991.

[21] Glasson, T.F. Jewish Symbols in the Greco Roman World. Princeton: Princeton University, 1998.

[22] Green, Joel B. Memahami Nubuatan. Jakarta: Persekutuan Pembaca Alkitab, 2005.

[23] Hendrikssen, William. Lebih Dari Pemenang. Jakarta: Momentum, 2007).

[24] Henry. Carl F. Basic Christian Doctrines. New York: Holt, 1962.

[25] Heppe, Heinrich. Reformed Dogmatics. Grand Rapids: Baker,1978.

[26] Herhard Kittel. Grand Rapids: Wm. B. Eerdmans Publishing Company, 1965.

[27] Hoekema, Anthony. Alkitab dan Akhir Zaman. Surabaya: Momentum, 2004..

[28] Kik, Marcellus. The Eschatology of
Victory. Philadelphia: Presbyterian and Reformed Co., 1971.

[29] Mauro, P.The Patmos Visions: A Study of the Apocalypse. Boston: Hamilton, 1945.

[30] Mealy, J.W. After the Thousand Years. Sheffield: JSOT, 1992.

[31] Michaels, J.R. Interpreting the Book of Revelation. Grand Rapids: Baker, 1992.

[32] Osterhaven, M.E. "Covenant Theology", ed.Walter A. Well dalam Evangelical Dictionary of Theology. Grand Rapids: Baker House, 1984

[33] Peter, Eddy. Teologi Perjanjian Versus Dispensasionalisme. Tangerang: STT Philadephia, 2004).

[34] Scott, J.M. Restoration of Israel. Downers Grove: InterVarsity, 1993.

[35] Selwyn, E.C. The Christian Prophets and the Prophetic Apocalypse. New York: Macmillan, 1990.

[36] Silva, M. Biblical Words and Their Meaning. Grand Rapids: Zondervan, 1983.

[37] Shedd, William G.T. Dogmatic Theology. Nashville: Nelson, 1980.

[38] Sperber, A. Judgement In Last Day. London: SCM, 1965.

[39] Strand, K.A. Chiastic Structure and Some Motifs in the Book of Revelation. New York: Newville, 1983.

[40] Torrance, T.F. The Apocalypse of John. New Haven: Yale University, 1958.

[41] Vanhoye, A. Old Testament Priests and the New Priest according to the New Testament. Petersham: St. Bede's, 1986.

[42] Van Til, Cornelius. "The idea of 
Jurnal Teologi \& Pelayanan ( Kerusso )

E-ISSN: 2714-9587

P-ISSN: 2407-554X

covenant theology has only in modern times been broadly conceived", Twentieth Century Encyclopedia. Grand Rapids: Baker Book House, 1955.

[43] Wainwright, A.W. Mysterious Apocalypse: Interpreting the Book of Revelation. Nashville: Abinkon, 1993.

[44] Walvoord, John. The Millennial Kingdom. Findley, Ohio: Dunham Publishing Company, 1959.

[45] White, R.F. The Millennial Kingdom. Missoula: Society of Biblical Literature, 1972.

[46] Wright, N.T. The Climax of the Covenant. Minneapolis: Fortress, 1992.

[47] Www.4himnet.com/history

[48] Www.allbygrace.com

[49] Www.geocities.com/theology

[50] Www.lifefebc.com/kovenan

[51]Www.reformedreader.org/fatherschurc $\mathrm{h}$

[52]Www.theologicalstudies.com/westmin ster/fatherchurch.

[53]Www.theologicalstudies.com/westmin ster/fatherchurch2.

[54]Www.wikipedia.com/covenanttheolog $\mathrm{y}$

[55]Www.wikipedia.org/wiki/covenantthe ology/pic. 